\title{
ОНТОЛОГІЧНІ УЯВЛЕННЯ ЗНАНЬ ДЛЯ ВДОСКОНАЛЕННЯ ДІАГНОСТИКИ ТА ЛІКУВАННЯ АТОПІЧНОГО ДЕРМАТИТУ У ДІТЕЙ
}

\author{
В. В. Бойко, Н. В. Яременко \\ Національна медична академія післядипломної освіти імені П. Л. Шупика
}

Запропонована онтологія знань із атопічного дерматиту у дітей. Проведено аналітичне оцінювання 12 статей на предмет зіставлення даних щодо діагностики та лікування хворих на атопічний дерматит із відповідним Протоколом діагностики та лікування дітей.

Ключові слова: атопічний дерматит, протоколи діагностики та лікування, онтологія медичних знань, додаткові критері діагностики та лікування.

\section{ОНТОЛОГИЧЕСКИЕ ПРЕДСТАВЛЕНИЯ ЗНАНИЙ ДЛЯ СОВЕРШЕНСТВОВАНИЯ ДИАГНОСТИКИ И ЛЕЧЕНИЯ АТОПИЧЕСКОГО ДЕРМАТИТА}

\author{
В. В. Бойко, Н. В. Яременко \\ Национальная медицинская академия последипломного образования \\ имени П. Л. Шупика
}

В статье представлены оценки 12 статей и сопоставление их с «Протоколом диагностики и лечения детей с атопическим дерматитом». На сегодняшний день одной из форм структурирования знаний является онтология. Онтология знаний по атопическому дерматиту позволяет структурировать сведения по диагностике и лечению данного заболевания у детей и позволяет рекомендовать ряд дополнений к существующему «Протоколу диагностики и лечения детей с атопическим дерматитом». При построении графологических схем выявлены различия по дополнительным критериям диагностики атопического дерматита у детей. Так, в Протоколе отсутствуют ряд, как нам кажется, важных признаков. К ним, в первую очередь, следует отнести: кератоконус, переднюю субкапсулярную катаракту, шелушение на лице и конечностях (Pityriasis alba), эритродермию, трещины за ушами.

Данные признаки чрезвычайно важны в постановке диагноза атопического дерматита у детей. Поэтому мы предлагаем существующий протокол дополнить данными дополнительными критериями и использовать его на практике.

Ключевые слова: атопический дерматит, протоколы диагностики и лечения, онтология медицинских знаний, дополнительные критерии диагностики и лечения.

\section{ONTOLOGICAL KNOWLEDGE TO IMPROVE DIAGNOSIS AND TREATMENT OF ATOPIC DERMATITIS}

\author{
V. V. Boyko, N. V. Yaremenko \\ National Medical Academy of Postgraduate Education by P. L. Shupyk
}

\begin{abstract}
The article describes the evaluation of 12 articles and their comparison with the "Protocol diagnosis and treatment of children with atopic dermatitis". Today ontology is one of the form of structuring knowledge. Ontology of knowledge of atopic dermatitis allows structure information of diagnosis and treatment of this disease in children and can recommend a number of amendments to the existing "Protocol of diagnosis and treatment of children with atopic dermatitis". When we built the graphological schemes we revealed differences concerning additional criteria of diagnostic of atopic dermatitis in children. So, in protocol important signs are absent, as it seems to us. These include, first of all: keratoconus, front subcapsular cataracts, peeling on the face and extremities (Pityriasis alba), erythroderma, cracks behind the ears.

These features are extremely important in the diagnosis of atopic dermatitis in children. Therefore, we propose to supplement existing protocol those additional criteria and use it in practice.
\end{abstract}

Key words: atopic dermatitis, protocols for diagnosis and treatment, ontology of medical knowledge, additional criteria for diagnosis and treatment.

(C) В. В. Бойко, Н. В. Яременко 
Вступ. Використання інформаційних технологій у системі охорони здоров'я набуває все більшого і більшого значення. Удосконалення професійної діагностики і лікування потребує структурованих знань, організованих у систему, яка, зрештою, і визначає якість формування конкретних дій, а в освітніх технологіях сприяє формуванню навичок та вмінь.

На сьогоднішній день однією з форм структурування знань $є$ онтологія. Перевагою онтології є системне об'єднання характеристик симптомів і ознак, що дозволяє легше виявити і показати логічні відносини в будь якій нозологічної одиниці. Ця специфіка набуває особливого значення при викладенні інформації, іiі аналізі, вважаючи виражену наочність досліджуваного матеріалу за деякими нозологіями.

Мета роботи - формулювання стратегії подальшого вдосконалення діагностики та лікування дітей iз атопічним дерматитом.

Матеріали та методи. Використовували розроблену на кафедрі медичної інформатики НМАПО імені П. Л. Шупика багаторівневу систему медичних онтологій [1]. Основне ії призначення - забезпечення статистичного моделювання патологічного процесу. Підкреслимо, що досліджень, присвячених статистичному моделюванню, за даними літератури вкрай мало. При цьому нестача теоретичних розробок, пов'язаних з моделюванням патологічного процесу, пов'язана з тим, шо в більшості досліджень процес представляється як двомірний. Водночас характер клінічних завдань зовсім не припускає використання всього масиву інформації, накопиченої в медицині. Відомо, що в завданнях діагностики захворювань, діагностики станів пацієнта, прогнозування тошо використовується до 40-50 симптомів. Зрозуміло, що завдань у клініці багато і загальний обсяг відомостей, необхідних для узагальнення, становить тисячі симптомів, ознак, симптомокомплексів тощо.

В роботі зроблено спробу формулювання загального завдання моделювання можливих патологічних процесів у паціснта на основі знань предметної області, до яких відносяться етіологія захворювань, значення ознак (в моменти їхнього спостереження), анатомо-фізіологічні особливості пацієнта.

Співвідношення між невідомими і параметрами нами поділені на кілька смислових груп, які визначаЮТь:

1. Знання про причинно-наслідкові відносини і причинно-наслідковий зв 'язок;

2. Ймовірні характеристики появи кожної ознаки на різних інтервалах часу;
3. Показники взасмозв'язку між симптомами та ознаками;

4. Причини патологічних станів, що входять в діагHO3.

3 метою формування переліку симптомів, ознак і симптомокомплексів для діагностики, вибору методу лікування і прогнозування результату лікування хворих з атопічним дерматитом детально проаналізовано відповідність (Протоколу діагностики та лікування дітей з атопічним дерматитом» (Наказ МО3 України від 27.12.2005 № 767 [2]) з останніми даними літератури, присвяченими цій проблемі. Використано матеріали 12 статей $з$ даної нозології.

У роботі для систематизації та структуризації відомостей $з$ атопічного дерматиту застосовані методичні прийоми побудови онтології знань (В. А. Тимченко, М. А. Князева, 2009 [3]; Н. В. Голиков, 2006 [4]; И. Б. Руденко [5]; В. А. Клименко [6]) і останні роботи по стандартизації діагностики та лікування атопічного дерматиту (Д. Ш. Мачарадзе, 2013 [7]; А. В. Зубаренко, О. А. Портнова, 2013 [8]; Rockville Pike, 2013 [9]).

Результати та їх обговорення. Поява Протоколу з діагностики та лікування атопічного дерматиту у дітей зіграла важливу роль у вдосконаленні надання медичної допомоги дітям з цією патологією. Проте подальше вивчення клініки атопічного дерматиту абсолютно необхідне. Суттєву допомогу в цьому процесі можуть надати сучасні підходи до структуризації знань.

При побудові графологічних схем виявлено відмінності щодо додаткових критеріїв діагностики атопічного дерматиту у дітей. Так, у Протоколі відсутній ряд, як нам здасться, важливих ознак. До них, насамперед, слід віднести: кератоконус, передню субкапсулярну катаракту, лущення на обличчі та кінцівках (Pityriasis alba), еритродермію, тріщини за вухами (рис. 1). Перераховані ознаки зустрічаються у багатьох роботах [7-15]. Розглянемо іх більш докладно.

Дискусійним у Протоколі діагностики та лікування дітей з атопічним дерматитом $€$ відсутність генетичних ознак: кератоконус та передня субкапсулярна катаракта.

Кератоконус (конічне випинання рогівки) - генетично обумовлене захворювання рогової тканини, що призводить до ії дистрофії та стоншання, в результаті чого рогівка замість сферичної (як це має бути в нормі), набуває неправильної (конічної) форми, що викликає значні і незворотні спотворення в оптиці ока. 


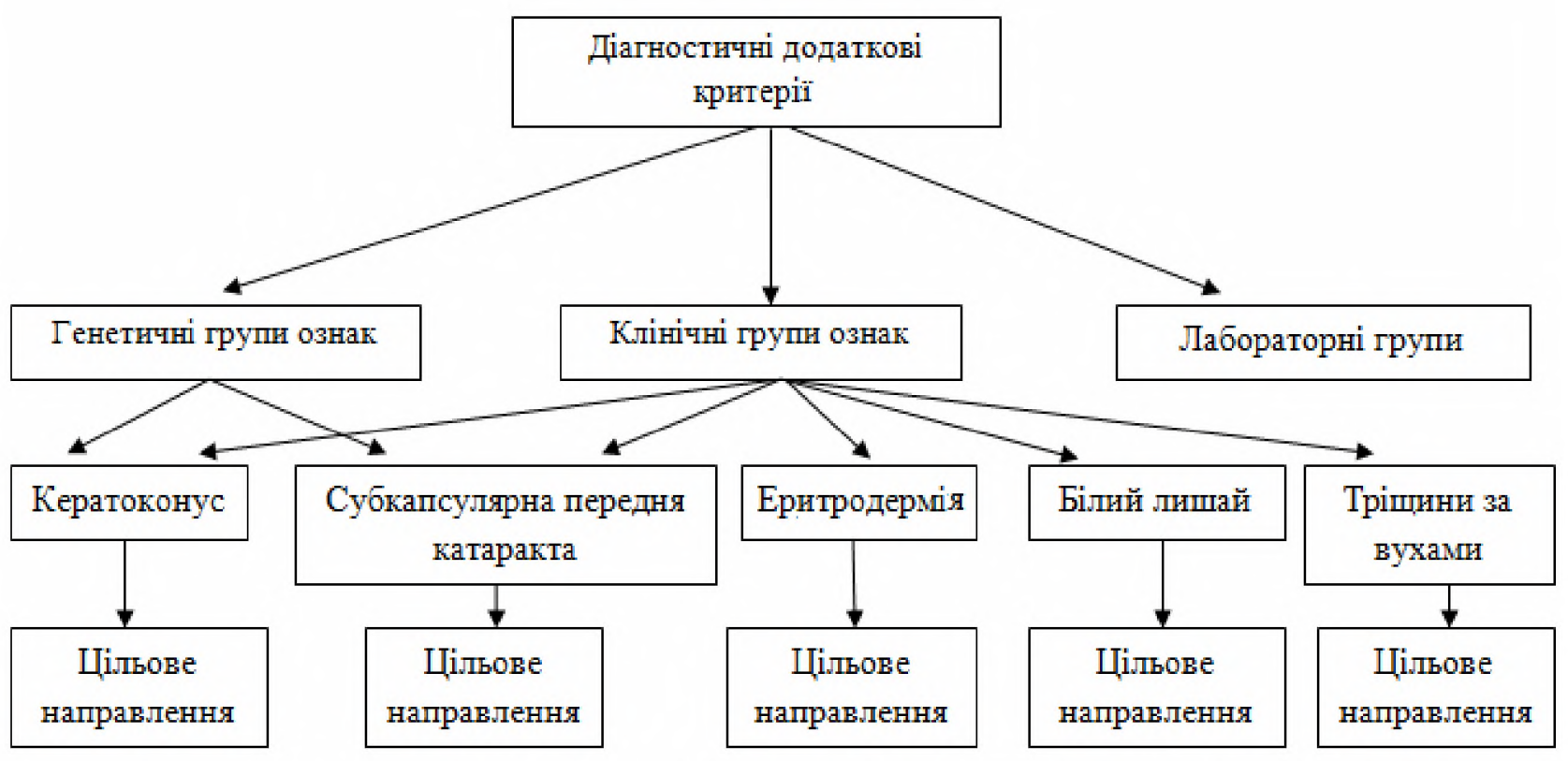

Puc. 1. Діагностичні додаткові критерії.

Діагностика кератоконусу розпочинається вже при повторному підборі окулярів, коли виявляється різке несиметричне збільшення рефракції, що обумовлює для досягнення оптимальної гостроти зору необхідність переходу від сферичних лінз до циліндричних та зміну осі циліндричних лінз. Рефрактометрія при кератоконусі виявляс неправильний астигматизм та міопію, обумовлені випинанням рогівки.

У спеціалізованих офтальмологічних клініках для виявлення кератоконусу використовують методи комп'ютерної рогівкової топографії, оптичної когерентної томографії рогівки, ендотеліальної мікроскопії.

Лікування кератоконусу здійснюють з урахуванням характеру перебігу кератоконусу (швидкості прогресування, схильності до рецидивів), лікування може бути диференційованим: безопераційним або хірургічним.

Консервативне лікування кератоконусу полягає в корекції зору за допомогою напівжорстких лінз, які ніби вдавлюють конус рогівки [16].

При розвитку гострого кератоконусу потрібна невідкладна допомога: закапування в око мідріатиків (мезатон, мідріацил та ін.), накладання тиснучої пов'язки на око 3 метою профілактики перфорації рогівки.

В консервативному лікуванні кератоконусу певне місце займас рогівковий крос-лінкінг, який дозволяс зміцнити рогівку, підвищити ії стійкість до деформації, зупинити розвиток або домогтися регресу кератоконусу.

На початковій стадії кератоконусу при достатній товщині рогової оболонки можливе проведення ек- симерлазерної процедури (ФРК + ФТК - фоторефракційна кератектомія + фототерапевтична кератектомія), що дозволяє скорегувати астигматизм, підвищити гостроту зору, зміцнити передні шари рогівки і сповільнити прогресування кератектазіі.

У деяких випадках з метою зменшення корнеальної деформації застосовують термокератопластику - нанесення коагулятором на периферію рогівки точкових аплікацій, які дозволяють домогтися сплощення рогівки. У хірургії кератоконусу використовують метод імплантації рогівкових кілець.

Класичною операцією при кератоконусі $є$ наскрізна або пошарова кератопластика, яка припускає видалення власної рогівки та імплантацію на ії місце донорського трансплантанта.

Катаракта - вроджене або набуте помутніння капсули або речовини кришталика, зокрема передня субкапсулярна катаракта розвивається у зв' язку з фіброзною метаплазією переднього епітелію кришталика. Субкапсулярна катаракта ускладнює читання, бачення на яскравому світлі, а вночі навколо джерел світла можуть з'являтися спалахи [17]. Морфологічно проявляється утворенням субкапсулярних вакуолей, «водяних щілин», які з'являються разом з ніжними точковими помутніннями під передньою капсулою.

Для виявлення захворювання застосовують стандартні (дослідження за допомогою щілинної лампи біомікроскопія, визначення гостроти і полів зору, вимірювання внутрішньоочного тиску, офтальмоскопія) та спеціальні (денситометрія, УЗД) методи офтальмологічного обстеження. 
Лікування субкапсулярної передньої катаракти розпочинається вже на початкових стадіях катаракти. Призначається медикаментозна терапія: очні краплі, що містять вітаміни ( $\mathrm{P}, \mathrm{A}, \mathrm{B}, \mathrm{C})$, антиоксиданти, амінокислоти, цистеїн, глутатіон, АТФ. Оскільки помутніння кришталика $\epsilon$ незворотним, терапія лише дозволяє уповільнити прогресування захворювання.

При початковій катаракті ефективне застосування фізіотерапевтичних приладів, які активізують обмінні процеси в передньому відрізку ока, покращують кровопостачання.

Хірургічне лікування є єдиним радикальним методом лікування від катаракти. У ході операції уражений катарактою кришталик видаляють, а на його місце встановлюють штучну інтраокулярну лінзу (ІОЛ). На сьогодні основними операціями, які виконують при катаракті, $\epsilon$ ультразвукова факоемульсифікація, екстракапсулярне або інтракапсулярне видалення кришталика 3 наступною установкою IOЛ.

Білий лишай (Pityriasis alba) характеризується плямами, які бувають круглими і овальними, з розмитими межами та різного розміру. Зазвичай ї діаметр дорівнює 2-4 сантиметрам. Якщо розглядати їх близько, то можна помітити незначне лущення цієї поверхні шкіри. Група ризику проявів білого ліхену включає в себе людей, які схильні до атопічного дерматиту, а також дітей, які мають ризик захворіти на бронхіальну астму, екзему та інші алергічні захворювання, що передаються спадково.

У діагностиці білого лишаю, насамперед, важливо диференціювати це захворювання з вітиліго, екземою, лейкодермою та різнобарвним лишаєм.

Лікування білого лишаю, як правило, не потрібне, захворювання проходить самостійно. При наявності запалення застосовують і гормональні мазі. У період загострення слід уникати сонця [18].

Еритродермія - узагальнювальна назва різних за етіологією та патогенезом шкірних захворювань, що характеризуються поширеним, нерідко універсальним почервонінням, набряком або інфільтрацією і лущенням шкіри. Лущення частіше пластинчасте, але може бути дрібним, висівковоподібним. Розрізняють еритродермії первинні та вторинні; останні нашаровуються на вже існуючі шкірні захворювання (атопічний дерматит, псоріаз, червоний плоский лишай тощо).

Еритродермії можуть перебігати гостро, підгостро i хронічно. Гострі еритродермії найчастіше $\epsilon$ наслідком підвищеної чутливості (алергії) до різних ліків (миш'як, ртуть, сульфаніламіди, антибіотики тощо). Хронічні еритродермії виникають як один із проявів загальних захворювань (атопічний дерматит, лейкози, лімфогранулематоз, грибоподібний мікоз тощо). Спільним для всіх еритродермій $є$ ризик часткової або загальної «шкірної недостатності» $з$ порушенням функцій шкіри (бар'єрної, терморегуляційної, захисноі). Крім цього, при тяжких еритродерміях визначається ушкодження внутрішніх органів (системи кровообігу, нирок, печінки), можливий і летальний випадок. Клінічна картина і результати огляду представлені ураженням шкіри і порушенням загального стану хворих. Шкірна симптоматика включає: значне почервоніння, лущення та інфільтрацію шкірного покриву; збільшення регіонарних лімфатичних вузлів. До позашкірної симптоматики (залежно від ступеня тяжкості еритродермій) належать погіршення загального сгану, лихоманка; порушення обміну речовин (водного, електролітного, білкового); ураження вну грішніх органів; вграта ваги аж до кахексії.

Еритродермія є складною для діагностики. Для всгановлення діагнозу необхідні докладний анамнез, зв'язок з попередніми хворобами шкіри, детальний аналіз клінічної картини захворювання, всебічне обстеження. Часто необхідна діагностична біопсія шкіри [19]. Дерматологічний статус: має значення колір шкіри, характер лущення, наявність інфільтрації, ексудації, гіперпігментації, свербежу шкіри, ураження їі придатків. При огляді слід звернути увагу на патогномонічні симптоми: ерозії, ліхенізації, екскоріації- характерні для еритродермії при атопічному дерматиті.

Лікування проводять залежно від встановленої причини. Хворі на еритродермію повинні перебувати в сгаціонарі, в окремій палаті, у якій підтримуєгься оптимальна температура і вологісгь повітря. При лікуванні хворого на еритродермію керуються насамперед характером ураження шкірного покриву. Рекомендується симптоматична прогизапальна терапія, яка включає також і дезінтоксикаційні засоби. Інтенсивна терапія необхідна для підгримання серцевої діяльності, корекції водно-електролітних порушень, поповнення сироваткових білків.

Тріщини за вухами характеризуються розчухами шкіри, викликають ущільнення і в результаті призводять до бактеріальних ускладнень

Лікування гріщин за вухами направлено на регідратацію та зволоження шкіри; обов'язково потрібно включаги в терапію ангигісгамінні препараги, які допомагають боротися зі свербежем. Зазвичай до захворювання приєднуюгься вторинні інфекції, які вимагаюгь проведення місцевої або комплексної ангибіогикогерапії. 
Клінічне застосування виділених ознак може виявитися корисним виходячи 3 простих правил, що використані у ряді робіт. Так, виявляється можливим застосовування принципу адитивності в розпізнаванні атопічного дерматиту. Автори (Д. Ш. Мачарадзе, 2013 [7]; Л. Д. Калюжная, 2006 [10]; И. Б. Руденко, 2006 [5]) вважають, що за наявності трьох (і більше) обов'язкових та трьох (і більше) додаткових ознак можна впевнено діагностувати атопічний дерматит.

Перелічені ознаки можуть бути використані при встановленні діагнозу атопічного дерматиту у дітей. Пропонується існуючий протокол доповнити даними додатковими критеріями та використовувати їх на практиці.

Висновки. 1. Запропоновано методику створення графологічної структури для систематизації інформації з атопічного дерматиту у дітей. Онтологія знань із атопічного дерматиту дозволяє структурувати відо-

\section{Лiтература}

1. Денисенко С. В. Використання приншипів медичної онтології для побудови сценарних моделей післядипломного навчання лікарів і провізорів/С. В. Денисенюю, О. П. Мінцер, О. Є. Стрижак//Медична інформатика та інженерія. -2013. -№ 2. - C. 18-23.

2. Протокол діагностики та лікування дітей 3 атопічним дерматитом : Наказ МОЗ України від 27.12.2005 за № 767 (додаток № 5) [Електронний ресурс]. - Режим доступу: http:// www.moz.gov.ua.

3. Тимченко В. А. Система преобразования информашии на основе проекций графовых структур / В. А. Тимченко, М. А. Князева // Information Technologies and Knowledge. 2009. - T. 3, № 1. - С. 37-55.

4. Голиков Н. В. Применение онтологий / Н. В. Голиков. Режим доступу: http://www.ict.nsc.ru/ws/YM2006/10628/ golikov.html

5. Руденко И. Б. Атопический дерматит / И. Б. Руденко // Здоров'я України. - 2006. - № 5. - С. 52-53.

6. Наб̆людение больного с атопическим дерматитом на педиатрическом участке [Електронний ресурс] / В. А. Клименко, В. П. Кандыба, Л. М. Адарюкова [и др.] // Специализированный портал для медработников. Новости медицины и фармации. - 2010 - № 322. - Режим доступу: http:/ /www.mif-ua.com/archive/article/12439.

7. Мачарадзе Д. Ш. Атопический дерматит и пищевая аллергия. Что общего? / Д. Ш. Мачарадзе // Лечащий врач. 2013. - №5. - C. 24-30.

8. Зубаренко А. В. Атопический дерматит: современные взгляды на этиопатогенез, клинику и диагностику заболевания / А. В. Зубаренко, О. А. Портнова // Здоровье ребёнка. -2008 . -№ 6(15). - 110-114.

9. Rockville Pike Atopic dermatitis [Електронний pecypc]. Режим доступу: http://www.nlm.nih.gov. мості про діагностику та лікування даного захворювання.

2. Підсумками Наказу є результати діагностики та лікування атопічного дерматиту у дітей. Дані літератури свідчать про можливе застосування додаткових критеріїв, використання яких може покращити діагностику та лікування атопічного дерматиту.

3. Онтологічні уявлення 3 атопічного дерматиту дозволяють рекомендувати ряд доповнень до існуючого «Протоколу діагностики та лікування дітей 3 атопічним дерматитом〉. До них відносять: наявність кератоконусу, передньої субкапсулярної катаракти, білих плям на обличчі і кінцівках (Pityriasis alba), еритродермії, тріщин за вухами.

4. Принцип адитивності може мати важливе значення в діагностиці та лікуванні атопічного дерматиту у дітей.

10. Калюжная Л. Д. Атопический дерматит. Современные вопросы диагностики и лечения / Л. Д. Калюжная // Клінічна імунологія. Алергологія. Інфектологія. - 2006. №1.- C. 19-22.

11. Святенко Т. В. Атопический дерматит: акценты на профилактике, или о правилах без исключений / Т. В. Святенко // Клінічна імунологія. Алергологія. Інфектологія. - 2009. №1. - C. 77-81.

12. Результаты терапии атопического дерматита у детей с использованием препарата левошетиризина гидрохлорида / Н. Л. Аряев, Н. Ю. Горностаева, И. М. Шевченко, Л. Л. Поплавская// Здоровье реб̈ёнка. - 2012. - № 7 (42). -41-44. 13. Tidy C. Atopic Dermatitis and Eczema [Електронний pecypc] / C. Tidy. - Режим доступу: http://www.patient.co.uk/ doctor/atopic-dermatitis-and-eczema.

14. Simpson E. L. Atopic dermatitis: a review of topical treatment options/E. L. Simpson//Current Medical Research \& Opinion. -2010. - Vol. 26(3). - P. 633.

15. Брандис Т. Современные подходы к терапии и контролюатопического дерматита [Електронний ресурс] / Т. Брандис // Специализированный портал для медработников. Новости медишины и фармации. - 2009. - № 1-2. - Режим доступу: http://www.mif-ua.com/archive/article/7096.

16. Фейнбаум К. Современные аспекты этиопатогенеза и лечения кератоконуса / К. Фейнбаум // Офтальмохирургия. -2011 . -№ 3. - С. 80-83.

17. Катаракта: симптомы и лечение [Електронний ресурс]. - Режим доступу: http://www OSimptoMer.ru.

18. Белый лишай [Електронний ресурс]. - 2013. - Режим доступу: http://www.MegaMedPortal.ru. - Заголовок 3 екрану.

19. Адаскевич В. П. Эритродермия / В. П. Адаскевич // Consilium medicum. Дерматология. -2009. -№2.-C. 28-33. 